\title{
Health effects of work and family transitions
}

Juli Simon Thomas
ejuliast@gmail.com

(Received March 2018 Revised September 2018)

\author{
Harvard University, USA
}

\section{Abstract}

Disruptive life events, including transitions in work or family structure, affect health. Research often focuses on one transition rather than thinking of an event framework in which respondents experience multiple transitions across qualitatively distinct domains. This paper contributes original evidence on the effects of event interaction, transition timing, and multiple occurrences of events on health outcomes. I look at employment loss, employment gain, marriage, and divorce as instances of disruptive transitions or instability in the life course; I analyse these events' effects on self-rated health and depression at ages 40 and 50 . I show that employment losses and divorces have significant negative effects on health, and employment gains and marriages show smaller positive effects or null effects. Higher counts of transitions lead to stronger effects on health. Respondents who are older at event occurrence show larger negative effects, suggesting that work and family instability at early ages is not as detrimental to health as such instability at later ages. These results show that there are similarities across work and family domains in effects on health outcomes; moreover, experiencing several transitions can lead to overlaps in effects that might lessen or worsen health outcomes overall.

\section{Keywords}

Health outcomes; disruptions; transitions; divorce; job loss

\section{Background}

Disruptive life events affect one's health: for example, job insecurity (Ali \& Avison, 1997; Ferrie, 2001) and marital dissolution (Prigerson, Maciejewski \& Rosenheck, 1999) have been shown to affect a variety of health outcomes. However, this knowledge is gained by focusing on one event at a time rather than thinking of events within a framework in which respondents experience multiple transitions across qualitatively distinct domains, which fits more closely with people's lived experiences. I bring together a focus on transitions in the domains of work and family, rather than considering these domains to be separate entities and analysing them as such. These domains have been shown to be co-incident (e.g. a job loss prompting a divorce (Charles \& Stephens, 2004; Sayer, England, Allison \& Kangas, 2011)) and are therefore a good starting point to explore these ideas. The goal is to see if transitions across domains evoke similar health effects, which would suggest that a framework that considers both domains (e.g. considering these events together as an example of disruptions or instability in the life course rather than analysing them as separate domains) is beneficial.

A secondary goal is to see how transitions interact when they are co-incident in a specified timeframe. I look at employment loss and gain as well as marriage and divorce, and I analyse the effects of these events on self-rated health and depression at age 40. By juxtaposing losses and gains across these two domains, I aim to disentangle the potential perceived benefits of gains and the expected negative effects of losses while maintaining cross-domain interaction. Since all of these transitions are frequently coincident 
across domains in people's lives, they form part of the life course context, and considering them in the same framework matters.

Beyond transitions being co-incident with each other, each event can occur more than once, and events can occur in early or later adulthood; in this paper, I consider these possibilities as well. I draw from life course theory when adding the timing and co-incidences of events in adulthood. I also build on Wheaton's (1990) contextual approach to stress effects, research on cumulative risk and resilience (Evans, Li \& Whipple, 2013; Masten, 2013; Masten, 2014; Masten \& Monn, 2015), and the social epidemiology of stress exposure across the life course (Ben-Schlomo \& Kuh, 2002; Bronfenbrenner 2004; Marmot 2005; Seeman \& Crimmins, 2001).

\section{The case for considering multiple transitions}

The events considered in this paper coexist in the span of a life course, occurring on the path or trajectory of a person's life (Elder 1998; Elder, Johnson \& Crosnoe, 2003; Wheaton \& Gotlib, 1997). Employment gains and losses could be considered 'linked' in that a person who experiences one often experiences the other at some point in the life course as well, as are marriages and divorces. But individuals also experience events in both domains within their lives, and this combining of events over time is what creates different life course pathways. When looking at one event's occurrence, I consider the other events as potentially co-occurring across a specific age span. As such, I analyse each transition both as a single event and as an event that could co-occur with other transitions in the life course.

Primarily based in sociology and public health, the concept of cumulative (dis)advantage suggests that disruptions in early life shape or inform future choices and opportunities (DiPrete \& Eirich, 2006). Indeed, it has been shown that early childhood disadvantage affects adult health (Repetti, Taylor \& Seeman 2002; Turner, Thomas \& Brown, 2016) and mortality (Hayward \& Gorman, 2004), and that childhood health affects adult socioeconomic outcomes (Palloni, 2006); this connection is complex (e.g. Link \& Phelan 1995) and riddled with intersectionalities (Adler \& Ostrove, 1999). Also related, in studies of health outcomes, the concept of allostatic load is "a measure of the cumulative physiological burden exacted on the body through attempts to adapt to life's demands" (Seeman, McEwen, Rowe, \& Singer, 2001); models of weathering (Geronimus, 1996) and accelerated aging (also called age-as-leveler; see e.g. Hayward, Miles, Crimmins, \& Yang, 2000) are similar efforts to understand the biological wear and tear of cumulative (dis)advantage and possible resilience (Lowe, Rhodes \& Waters 2015). All of these conceptual frameworks assume that previous events in life matter and perhaps persist in affecting future outcomes; it is possible for transitions to happen as a result of other transitions or be otherwise connected, especially when looking across a longer age span. Situated in life course theory, Wheaton (1990) calls this a person's "role history" prior to an event (p. 209).

The ideas of cumulative disadvantage, differential biological wear and tear (allostasis, weathering, accelerated aging), and role history suggest that, when considering the effects of one transition, other transitions matter as well, in some way. However, these are large bodies of literature, and this paper sets out neither to prove nor disprove these conceptual theories. Instead, I use these theories to underscore that it is important to consider the fact that other events matter when considering the effects of a single transition. Particularly in the realms of work and family, we find events that frequently occur in people's lives, and it is possible that they will co-occur. Thus, I posit that considering experiences of transitions across qualitatively distinct domains, and multiple occurrences of all disruptive transitions, matters for health outcomes. I remain agnostic on the reasons why multiple transitions occur.

\section{Transitions as positive, negative, normative, or disruptive}

It seems likely that the nature of the transition matters - one would guess that marriage is more of a positive event as compared to employment loss, generally speaking. Life course theory contends that some events are normative, such as completion of schooling, first marriage, or retirement (Riley \& Riley, 1994; Uhlenberg \& Mueller, 2004). Some events are non-normative, such as job loss; these events are sometimes unexpected (McLeod \& Almazan, 2004) and could be considered turning points (Wheaton, 1997; Wheaton \& Gotlib, 1997). Life course theory states that timing matters (Elder, Johnson, \& Crosnoe, 2003; Mayer, 2009), and as such, events that are normative at some times are non-normative when off-time (McLeod \& Almazan, 2004). I refer to all the events considered in this 
paper as disruptive transitions, though I do not imply negative effects with this terminology. Indeed, some of the events could be beneficial, and the timing of the events could dictate the effects' directionality. However, they do have the potential to disrupt the life course, and therefore I use this terminology. The work and family transitions considered in this paper are specific instances of disruptive transitions; there are many other transitions that could be considered within this framework, including but not limited to residential moves and health-related events (e.g., diagnoses of chronic illnesses, transition into parenthood). I focus on work and family transitions due to their likelihood of occurrence and co-occurrence. By comparing and contrasting transitions that are likely to occur and co-occur, I set the stage for considering other transitions. I address timing by analysing events in early versus later adulthood to see if there are differences in effects.

\section{Effects of employment transitions}

Loss of employment has been widely shown to affect physical and mental health negatively (Ali \& Avison, 1997; Backhans \& Hemmingsson, 2011; Bambra, 2011; Bartley, Ferrie \& Montgomery, 2006; Burgard, Brand \& House, 2009 Kasl \& Jones, 2000; Kessler, House \& Turner, 1987; Paul \& Moser, 2009; Sleskova et al., 2006). It has been linked to higher mortality rates (Bambra, 2011; Morris, Cook \& Shaper, 1994), especially during recessionary periods (Noelke \& Beckfield, 2014). There is less work on the effects of employment gain on health. Some scholars have considered the possibility of reemployment in the aftermath of a job loss, and there is evidence that the damage of a job loss can be repaired by a subsequent job gain (Bartley, Ferrie \& Montgomery, 2006; Kessler, Turner \& House, 1989). However, Ali \& Avison (1997) show that both single and married mothers transitioning into employment experience feelings of distress (single mothers for financial reasons and married mothers for increased caregiving stress). More generally, employment instability has been shown to be detrimental to health (Ferrie, Shipley, Marmot, Stansfeld, \& Davey Smith, 1998; Ferrie, 2001; Frech \& Damaske, 2012), implying that employment losses and gains are intricately linked. It is worth noting that work environment matters: poor working conditions have been linked to lower health outcomes (Bambra, 2014).

\section{Effects of marital transitions}

Marriage is generally shown to aid one's health (Frech \& Williams, 2007; Uecker, 2012), even leading to lower mortality (Koball, Moiduddin, Henderson, Goesling, \& Besculides, 2010). On the other hand, divorce has been shown to negatively impact one's health (Blekesaune, 2008; Hughes \& Waite, 2009; Prigerson, et al., 1999). Some authors find that this connection holds especially true for women (Liu \& Umberson, 2008) despite marital selection effects by health status (Cheung \& Sloggett, 1998), though others find similar effects for men and women (Blekesaune, 2008). There is variation in the effects of marriage and divorce, in that leaving a harmful marriage can actually be beneficial (Booth \& Amato, 2001), staying in a dysfunctional marriage can be damaging to one's health (Coyne \& DeLongis, 1986; Hawkins \& Booth, 2005; Kiecolt-Glaser \& Newton, 2001), effects can vary based on the number of times one has entered and exited marital statuses (Blekesaune, 2008), and personal characteristics matter (Frech \& Williams, 2007; Waldron, Hughes \& Brooks, 1996). I focus on the average overall effects for both events.

\section{Data and methods}

I use data from the National Longitudinal Survey of Youth, 1979 (NLSY79) (U.S. Bureau of Labor Statistics, 2012). The NLSY79 is a cohort study of 12,686 respondents in the United States who were first interviewed in 1979 and followed annually through 1994, biannually since then (most recently in 2012). The sample began with youth born between 1957 and 1964; from a random sample of housing units in selected U.S. areas and a random sample of members of the military from Department of Defense records, participants were first screened and then assigned to sample groups. The NLSY79 is one of the most widely used longitudinal studies in the United States for its thoroughness and length. These factors also make it a good choice for looking at the multiple influences of work and family transitions over the life course.

The NLSY79 includes an insightful module of questions about the respondent's health that was given when the respondent was forty years old. Initially implemented to look at health limitations on work, this module was changed to provide a wealth of baseline health information at middle age. The main variables I use to assess health are 
from this module: a measure of self-rated health and a measure of depression. Self-rated health is assessed on a five-point Likert scale (excellent, very good, good, fair, poor), from which I create a binary indicator of good health (excellent, very good, good) or bad health (fair, poor). Self-rated health has been established as a good measure of overall health (Idler \& Benyamini, 1997), and creating a binary measure has ample precedent (Case \& Paxson, 2005). The depression score is created using the CES-D ${ }^{1}$ set of questions; a score of 16 or above is considered an indicator of depression and a score of less than 16 on this scale means the respondent is not depressed. I use this cut-off to create a binary measure of depression, as suggested in NLSY79 documentation.

The health module includes measures of physical and mental health based on the SF- $12^{2}$ summary scale. Correlations between self-rated health and the included measure of physical health, and between the CES-D depression outcomes and the measure of mental health are high (0.61 and 0.66, respectively). I therefore use the self-rated health and CES-D measures for my analyses, as the latter is repeated at various intervals (necessary for sensitivity analyses) and the former encompasses the respondents' viewpoints. When possible, I point out where results for the measures chosen for this paper deviate from results from physical and mental health scores.

I start with the full sample of 12,686 respondents. I remove respondents who did not complete the health module's questions about selfrated health and the battery of questions that encompass the CES-D at age $40(n=4,328)$; most of these $(n=4,223)$ do not complete these questions because they are not eligible for the interview due to age requirements or they were dropped from the sample in those years because they were part of the military or poor-white oversample (Bureau of Labor Statistics, 2016). I remove individuals who are missing either measure due to question refusal or choice to skip the questions $(n=105)$. I do not impute health values for the refusal/chosen skip individuals since these are my outcome variables (Wooldridge, 2006). I remove those who did not complete physical and mental health scores and a question about health limitations on work at age 18 that is used as a baseline health score in some models $(n=111)$. My final sample includes 8,247 respondents.
Age at transition may matter (Kasl \& Jones, 2000). To investigate possible age-based variation, I look at disruptive transitions experienced between the ages of 18 and 25 and again between the ages of 26 and 40 . This roughly divides events into occurring during early versus mid-life working and relationship histories. This decision is also based on the average age of attaining a final level of education (Kena et al., 2016) and of first marriage (Goldstein \& Kenney, 2001) during the waves of the health module's administration (1998-2002). In other words, ages 18-25 represent a more unstable time, during which respondents are completing education, entering the workforce for the first time, and transitioning into marriage. Ages $26-40$, by contrast, represent a time when most respondents have concluded their education and have already entered the workforce. I look at events by number of occurrences; for employment events, this means looking at outcomes for one, two, or three events, and for marital events, this means looking at events happening once or twice. Thus, I create a set of event variables, for each event considered, as events ever occurring during the specified age range and as a count of events occurring during that age range; this includes events I can observe in the time period covered by the NLSY79. I separately analyse events ever occurring and event counts.

There are a number of important covariates to include; health outcomes have been shown to vary by factors such as social class (Adler et al., 1994; Blane, 2006; Marmot, 2005), education (Cutler \& Lleras-Muney, 2010; Schnittker, 2004), and race (Krieger, Rowley, Hermann, Avery, \& Phillips, 1993; Nazroo \& Williams, 2006). I control for gender, race/ethnicity (Black, Hispanic), high school completion (12 years of education) at age 40 , any college attendance (between 12 and 16 years of education) at age 40 , college completion (16 or more years of schooling) at age 40, ability (measured by the ASVAB in 1981), number of children at age 40 , count of years on welfare between ages 18 and 40, health limitations on work at age 18, Rotter Locus of Control score (measured in 1979), and the Rosenberg Self-Esteem Scale (10item; measured in 1980). The last three variables provide a baseline of physical and mental health; though it would be preferable and advantageous to have the same health measures at the start of the survey as the outcome variables, these are not available. (This choice is further discussed in a later 
section.) Given research that shows differences by gender in terms of event experience (Nathanson, 1980) and health outcomes (Bird \& Rieker, 1999; Crimmins \& Saito, 2001; Mirowsky, 1996; Moen \& Chermack, 2005), I stratify analyses by gender to examine differences.

Logistic regression models are used to determine effects of events on health outcomes at age 40. Regressions are unweighted, following recommendation from the NLSY79 (Bureau of Labor Statistics, 2016) and email correspondence with NLS staff (S. McClaskie, personal communication, April $6,2016)$. Since models are not weighted, I decided not to weight the descriptive statistics I report, since these are simple reports and not analyses. For some models, I report both results for the full sample and results stratified by gender.

\section{Results}

\section{Descriptive results}

I start with an overview of descriptive variables and outcomes. Table 1 shows the means for covariates, relevant health variables, and event variables (all events occurring before age 40 ). For both depression and fair/poor health scores, more respondents are female and Black. Those in poor mental or physical health have fewer years of education, on average, and especially lower rates of college completion. They have lower average ability scores, higher Locus of Control scores (i.e. they feel less control over their lives), lower self-esteem scores, and slightly more children. They have spent significantly more years receiving welfare of some kind (AFDC, food stamps, SSI, or any other public assistance). Those in poor mental and physical health show lower physical and mental scores, as expected, and a slightly higher rate of health limitations on work at age 18.

Descriptive statistics show differences in event variables as well. Those who rate as depressed and those in fair or poor health experience more employment events, on average, particularly losses. They experience fewer marriages and more divorces. This illustrates that those in poorer physical and mental health seem to experience more disruptive events (and fewer positive events such as marriages), over the course of their lives. In this sample, $24 \%$ of respondents experience all four events before age 40 , while $31 \%$ experience any three, illustrating that experiencing one event in the context of other events is common.

\section{Logistic regression model results}

In tables 2 and 3, I report the effect (log-odds) for each event separately (that is, a model looking at employment loss does not control for employment gain, marriage, or divorce) on depression and self-rated health, respectively. These models include events occurring between ages 18 and 40 (the variable is coded as 1 if events ever occurred, so this does not control for the number of times an event may have occurred in this time period), and depression and self-rated health are measured at age 40 . Once controls for gender, race, education, ability, number of children, welfare receipt, health limitations on work, Locus of Control, and self-esteem are included, employment losses and divorces decrease self-rated health and increase depression. For self-rated health, these effects are stronger for men than for women. Interestingly, the reverse is true for the effect of employment loss on depression. However, these models do not account for events' co-incidence in the life course, nor do they address timing.

To analyse co-incidence, in tables 2 and 3, I report the effect for each event from models that include all four events on depression and self-rated health (listed as 'one model'). With controls, coefficient values for employment losses and divorces increase, and marriage is shown to be protective of depression, significantly so for women. Employment gains show counter-effects to losses, and marriages to divorces as well. Given this more nuanced view of a variety of events occurring in the life course, in the rest of the models in this paper I include all events in the same model.

As shown in descriptive statistics, it is not unlikely for people to experience events more than once, particularly for employment events. To address this variation, I create dummy variables for counts of one, two, three employment losses and gains, and counts of one or two marriages and divorces. I combine this count distinction with variation in timing in adulthood. Thus, I create the aforementioned indicators for ages 18-25 and 2640 separately. I then run models containing all events, at each count (e.g. 1, 2, 3 occurrences), for each age group, with controls. The results from these models, for depression and self-rated health, are shown in tables 4 and 5 . As the model constant, $\mathrm{R}$-squared, $\mathrm{n}$, and other information shows in the bottom rows of the tables, each set of two columns is one model; in other words, each of those tables 


\section{Table 1: Descriptive Statistics (means), by Outcome Variables} (CES-D Score and Self-Rated Health Score)

\begin{tabular}{|c|c|c|c|c|}
\hline & $\begin{array}{c}\text { CES-D score }<16 \\
\text { (not depressed) }\end{array}$ & $\begin{array}{c}\text { CES-D score } \geq 16 \\
\text { (depression) }\end{array}$ & $\begin{array}{l}\text { Self-rated health } \\
\text { (excellent, very } \\
\text { good, good) }\end{array}$ & $\begin{array}{c}\text { Self-rated health } \\
\text { (fair, poor) }\end{array}$ \\
\hline \multicolumn{5}{|l|}{ Covariates } \\
\hline Male $(0 / 1)$ & 0.494 & 0.360 & 0.499 & 0.429 \\
\hline Black (0/1) & 0.304 & 0.405 & 0.295 & 0.382 \\
\hline Hispanic (0/1) & 0.194 & 0.194 & 0.187 & 0.241 \\
\hline Years of education attained (by age 40 ) & 13.212 & 12.036 & 13.354 & 12.004 \\
\hline High school only ( $0 / 1$; by age 40$)$ & 0.434 & 0.482 & 0.423 & 0.517 \\
\hline High school (0/1; by age 40$)$ & 0.892 & 0.761 & 0.906 & 0.765 \\
\hline College attendance $(0 / 1 ;$ by age 40$)$ & 0.214 & 0.207 & 0.253 & 0.172 \\
\hline College completion $(0 / 1$; by age 40$)$ & 0.214 & 0.072 & 0.230 & 0.076 \\
\hline Ability $(-3-3)$ & 0.039 & -0.432 & 0.084 & -0.364 \\
\hline Rotter Locus of Control & 8.708 & 9.468 & 8.635 & 9.362 \\
\hline Self-esteem & 478.287 & 449.172 & 481.164 & 452.341 \\
\hline Number of children (by age 40 ) & 1.924 & 2.176 & 1.907 & 2.083 \\
\hline Welfare (between ages 18 and 40) & 0.361 & 0.712 & 0.329 & 0.648 \\
\hline Welfare (count, between ages 18 and 40) & 1.852 & 5.311 & 1.578 & 4.266 \\
\hline \multicolumn{5}{|l|}{ Health variables } \\
\hline Physical score (at age 40 ) & 5226.390 & 4359.054 & 5379.249 & 4013.518 \\
\hline Mental score (at age 40 ) & 5357.614 & 3230.703 & 5395.106 & 4660.735 \\
\hline Health limits (in 1979) & 0.046 & 0.077 & 0.042 & 0.076 \\
\hline \multicolumn{5}{|l|}{ Event variables, before age 40} \\
\hline Employment loss (ever) & 0.709 & 0.820 & 0.700 & 0.791 \\
\hline Employment gain (ever) & 0.810 & 0.860 & 0.807 & 0.838 \\
\hline Employment event (ever) & 0.830 & 0.887 & 0.826 & 0.873 \\
\hline Marriage (ever) & 0.727 & 0.613 & 0.736 & 0.643 \\
\hline Divorce (ever) & 0.356 & 0.504 & 0.349 & 0.430 \\
\hline Marital event (ever) & 0.747 & 0.667 & 0.754 & 0.679 \\
\hline Employment loss (count) & 1.360 & 1.896 & 1.325 & 1.710 \\
\hline Employment gain (count) & 1.648 & 2.018 & 1.630 & 1.851 \\
\hline Employment event (count) & 3.008 & 3.914 & 2.954 & 3.560 \\
\hline Marriage (count) & 0.913 & 0.829 & 0.920 & 0.851 \\
\hline Divorce (count) & 0.445 & 0.667 & 0.436 & 0.552 \\
\hline Marital event (count) & 1.358 & 1.495 & 1.356 & 1.403 \\
\hline$N$ (out of 8,247 ) & 8,025 & 222 & 7,183 & 1,064 \\
\hline Proportion of total sample & 0.97 & 0.03 & 0.87 & 0.13 \\
\hline
\end{tabular}

Notes: Both count and ever variables refer to events or coverage between the ages of 18 and 40 years. Sample includes all respondents who were included in the additional health questionnaire at age 40 and completed the CES-D and self-rated health questions and were non-missing on all other covariates. 
Table 2: The Effects of Disruptive Events (at ages 18-40)

on Depression at age 40

\begin{tabular}{|c|c|c|c|}
\hline Event & All & Men & Women \\
\hline \multicolumn{4}{|l|}{ Separate models } \\
\hline Employment losses & $0.383 *$ & -0.153 & $0.619 *$ \\
\hline Employment gains & 0.193 & -0.131 & 0.295 \\
\hline Marriage & -0.091 & -0.012 & -0.182 \\
\hline Divorce & $0.462 * *$ & $0.595 *$ & $0.346+$ \\
\hline \multicolumn{4}{|l|}{ One model } \\
\hline Employment losses & $0.434+$ & -0.183 & $0.730 *$ \\
\hline Employment gains & -0.166 & 0.026 & -0.239 \\
\hline Marriage & $-0.487+$ & -0.500 & $-0.532 *$ \\
\hline Divorce & $0.696 * * *$ & $0.850 * *$ & $0.586 * *$ \\
\hline $\begin{array}{l}\text { Notes: Results are lo } \\
\text { race, education, abil } \\
\text { limitations on work, } \\
\text { Self-Esteem Scale sc } \\
+p<.10 * p<.05\end{array}$ & $\begin{array}{l}\text { dds. All model } \\
\text { number of chi } \\
\text { er Locus of C } \\
.01 * * * p<\end{array}$ & $\begin{array}{l}\text { nclude cont } \\
\text { ren, welfare } \\
\text { trol score, a } \\
01 \text { (two-tai }\end{array}$ & $\begin{array}{l}\text { for gender, } \\
\text { eipt, health } \\
\text { osenberg } \\
\text { tests) }\end{array}$ \\
\hline
\end{tabular}

Table 3: The Effects of Disruptive Events (at ages 18-40) on Self-Rated Health at age $\mathbf{4 0}$

\begin{tabular}{|c|c|c|c|}
\hline Event & All & Men & Women \\
\hline \multicolumn{4}{|l|}{ Separate models } \\
\hline Employment losses & $-0.366 * * *$ & $-0.507 * * *$ & $-0.225+$ \\
\hline Employment gains & -0.144 & -0.197 & -0.064 \\
\hline Marriage & -0.014 & 0.028 & -0.001 \\
\hline Divorce & $-0.197 * *$ & $-0.305 * *$ & -0.086 \\
\hline \multicolumn{4}{|l|}{ One model } \\
\hline Employment losses & $-0.474 * * *$ & $-0.679 * * *$ & $-0.301 *$ \\
\hline Employment gains & 0.218 & 0.321 & 0.154 \\
\hline Marriage & 0.105 & 0.18 & 0.069 \\
\hline Divorce & $-0.234 * *$ & $-0.375 * *$ & -0.111 \\
\hline $\begin{array}{l}\text { Notes: Results are lo } \\
\text { race, education, abil } \\
\text { limitations on work, } \\
\text { Esteem Scale score. } \\
+p<.10 * p<.05\end{array}$ & $\begin{array}{l}\text { dds. All moder } \\
\text { number of chil } \\
\text { ter Locus of Cc } \\
.01^{* * *} p<\end{array}$ & $\begin{array}{l}\text { nclude contro } \\
\text { en, welfare r } \\
\text { trol score, anc } \\
1 \text { (two-taile }\end{array}$ & $\begin{array}{l}\text { Or gender, } \\
\text { ipt, health } \\
\text { osenberg Self- } \\
\text { ests) }\end{array}$ \\
\hline
\end{tabular}


Table 4: The Effects of Disruptive Events (at ages 18-25 \& 26-40) on Depression at age 40, by timing and incidence

\begin{tabular}{|c|c|c|c|c|c|c|c|c|c|}
\hline \multirow{2}{*}{\multicolumn{2}{|c|}{ Event }} & \multicolumn{3}{|c|}{ All respondents } & \multicolumn{2}{|c|}{ Men } & \multicolumn{3}{|c|}{ Women } \\
\hline & & $18-25$ & \multicolumn{2}{|l|}{$26-40$} & $18-25$ & \multirow[t]{2}{*}{$26-40$} & \multirow[t]{2}{*}{$18-25$} & \multicolumn{2}{|c|}{$26-40$} \\
\hline \multicolumn{8}{|c|}{ Employment losses } & & \\
\hline & $1 x$ & 0.212 & 0.942 & $* * *$ & 0.178 & 0.535 & 0.199 & 1.120 & $* * *$ \\
\hline & $2 x$ & $0.617+$ & 1.492 & $* * *$ & 0.880 & 0.424 & 0.553 & 1.947 & $* * *$ \\
\hline & $3 x$ & $1.892 * * *$ & 1.918 & $* * *$ & $2.242 * *$ & 1.058 & $1.851 * *$ & 2.342 & $* * *$ \\
\hline \multicolumn{10}{|c|}{ Employment gains } \\
\hline & $1 x$ & -0.092 & -0.910 & $* * *$ & -0.273 & $-0.738 *$ & -0.054 & -1.053 & $* * *$ \\
\hline & $2 x$ & $-0.595 *$ & -1.095 & $* * *$ & $-1.206 *$ & -0.639 & -0.396 & -1.309 & $* * *$ \\
\hline & $3 x$ & $-1.053+$ & -1.556 & $* * *$ & 1.188 & -0.722 & $-1.259+$ & -1.909 & $* * *$ \\
\hline \multicolumn{10}{|l|}{ Marriage } \\
\hline & $1 x$ & $-0.399 *$ & -0.729 & $* * *$ & -0.364 & -0.426 & $-0.562 *$ & -0.955 & $* * *$ \\
\hline & $2 x$ & -0.302 & -0.487 & & -1.167 & -1.019 & -0.045 & -0.320 & \\
\hline \multicolumn{10}{|l|}{ Divorce } \\
\hline & $1 x$ & -0.189 & 0.977 & $* * *$ & 0.587 & $1.225 * * *$ & -0.001 & 0.873 & $* * *$ \\
\hline & $2 x$ & 0.685 & 0.951 & $*$ & --- & -0.035 & 0.839 & 1.164 & $*$ \\
\hline Constant & & \multicolumn{3}{|c|}{$-4.001 * * *$} & \multicolumn{2}{|c|}{$-4.275 * * *$} & \multicolumn{2}{|c|}{$-3.738^{* * *}$} & \\
\hline$L R \chi^{2}$ & & \multicolumn{3}{|l|}{235.90} & \multicolumn{2}{|c|}{123.74} & \multicolumn{2}{|c|}{139.62} & \\
\hline$P>\chi^{2}$ & & \multicolumn{3}{|l|}{0.000} & \multicolumn{2}{|c|}{0.000} & \multicolumn{2}{|c|}{0.000} & \\
\hline Pseudo $R^{2}$ & & \multicolumn{3}{|l|}{0.124} & \multicolumn{2}{|c|}{0.171} & \multicolumn{3}{|c|}{0.121} \\
\hline$n$ & & \multicolumn{3}{|l|}{7,712} & \multicolumn{2}{|c|}{3,711} & \multicolumn{2}{|c|}{3,978} & \\
\hline
\end{tabular}

Notes: Results are log-odds. All models include controls for gender, race, education, ability, number of children, welfare receipt, health limitations on work, Rotter Locus of Control score, and Rosenberg Self-Esteem Scale score. $+\mathrm{p}<.10 * \mathrm{p}<.05 * * \mathrm{p}<.01 * * * \mathrm{p}<.001$ (two-tailed tests)

Table 5: The Effects of Disruptive Events (at ages 18-25 \& 26-40) on Self-Rated Health at age 40, by timing and incidence

\begin{tabular}{|c|c|c|c|c|c|c|c|c|}
\hline \multirow{2}{*}{\multicolumn{2}{|c|}{ Event }} & \multicolumn{2}{|c|}{ All respondents } & \multicolumn{2}{|c|}{ Men } & \multicolumn{3}{|c|}{ Women } \\
\hline & & $18-25$ & $26-40$ & $18-25$ & $26-40$ & \multirow[t]{2}{*}{$18-25$} & \multicolumn{2}{|c|}{$26-40$} \\
\hline \multicolumn{8}{|c|}{ Employment losses } & \\
\hline & $1 x$ & $-0.169+$ & $-0.928 * * *$ & -0.122 & $-1.264 * * *$ & -0.199 & -0.708 & $* * *$ \\
\hline & $2 x$ & $-0.429 * *$ & $-1.578 * * *$ & -0.293 & $-1.631 * * *$ & $-0.536 *$ & -1.528 & $* * *$ \\
\hline & $3 x$ & $-1.188 * * *$ & $-1.956 * * *$ & $-1.283 * *$ & $-2.106 * * *$ & $-1.121 *$ & -1.876 & $* * *$ \\
\hline \multicolumn{9}{|c|}{ Employment gains } \\
\hline & $1 x$ & 0.066 & $0.592 * * *$ & 0.081 & $0.778 * * *$ & 0.062 & 0.512 & $* * *$ \\
\hline & $2 x$ & $0.394 * *$ & $1.302 * * *$ & $0.379+$ & $1.188^{* * *}$ & $0.420 *$ & 1.357 & $* * *$ \\
\hline & $3 x$ & $0.907 * *$ & $1.582 * * *$ & $1.050 *$ & $1.578^{* * *}$ & $0.812 *$ & 1.547 & $* * *$ \\
\hline \multicolumn{9}{|l|}{ Marriage } \\
\hline & $1 x$ & 0.113 & 0.082 & 0.138 & 0.170 & 0.142 & 0.016 & \\
\hline & $2 x$ & 0.209 & 0.214 & 0.175 & 0.343 & 0.275 & 0.094 & \\
\hline \multicolumn{9}{|l|}{ Divorce } \\
\hline & $1 x$ & $-0.226+$ & $-0.198 *$ & $-0.383+$ & $0.363 *$ & -0.119 & -0.061 & \\
\hline & $2 x$ & $-0.696+$ & -0.259 & -0.588 & -0.209 & -0.763 & -0.259 & \\
\hline Constant & & \multicolumn{2}{|c|}{$2.024^{* * *}$} & \multicolumn{2}{|c|}{$2.060^{* * *}$} & \multicolumn{3}{|c|}{$1.831^{* * *}$} \\
\hline$L R \chi^{2}$ & & \multicolumn{2}{|l|}{737.75} & \multicolumn{2}{|c|}{344.72} & \multicolumn{2}{|c|}{412.64} & \\
\hline$P>\chi^{2}$ & & \multicolumn{2}{|l|}{0.000} & \multicolumn{2}{|c|}{0.000} & \multicolumn{2}{|c|}{0.000} & \\
\hline Pseudo $R^{2}$ & & \multicolumn{2}{|l|}{0.126} & \multicolumn{2}{|c|}{0.132} & \multicolumn{2}{|c|}{0.128} & \\
\hline$n$ & & \multicolumn{2}{|l|}{7,712} & \multicolumn{2}{|c|}{3,734} & \multicolumn{2}{|c|}{3,978} & \\
\hline
\end{tabular}

Notes: Results are log-odds. All models include controls for gender, race, education, ability, number of children, welfare receipt, health limitations on work, Rotter Locus of Control score, and Rosenberg Self-Esteem Scale score. $+\mathrm{p}<.10^{*} \mathrm{p}<.05 * * \mathrm{p}<.01 * * * \mathrm{p}<.001$ (two-tailed tests) 
contains results from three models in total. For employment losses and gains, there is a clear upward gradient for effects on both outcomes as event counts increase and age at event increases. Marriage is associated with decreases in depression, particularly when it occurs in the later age range, but not for those who experience more than one marriage. Divorces are associated with decreases in self-rated health regardless of their timing, but they are only associated with increases in depression when they occur in the later age range.

It is again clear that employment disruptions affect men's self-rated health but not mental health, whereas women's physical and mental health are affected by these disruptions. Marriage is associated with decreases in depression in women but has no significant effects for men. Divorce is associated with increases in depression in women only.

These results suggest that disruptive events do affect both self-rated health and depression, in slightly different ways for men and women. Coincidence of events matters, as does the number of occurrences and timing in adulthood. Analyses using physical and mental health scores in lieu of self-rated health and depression scores produced similar results. However, there are several issues that arise with this analysis: reverse causality, temporal distance from event to outcome, and age ranges and time-variant characteristics. I address these concerns in the next sections.

\section{Addressing reverse causality}

Reverse causality is a fundamental issue in this analysis: those who are in poorer mental or physical health could be disproportionately likely to experience events (Adler \& Ostrove, 1999; Lerner et al., 2004). The results reported include a control for health limitations at age 18 which somewhat addresses this concern. In this section, I use other pre-treatment variables to further examine the possibility of selection. I also run models to examine pre-treatment heterogeneity, where I treat selection into events by health as a form of heterogeneity.

The NLSY79 health module for age 40 is repeated at age 50 , though the sample size is quite a bit smaller than the age 40 module, with the total sample for the age 50 module being 1,603 respondents. However, this allows for linkages from age 40 to age 50 for both self-rated health and depression variables. Event variables that pre-date age 40 cannot be included when using health scores at age 40 as a control in models, so I create new event variables that only include events between ages 40 and 50. Due to data limitations, I code these variables as having occurred any number of times versus never occurring; I lose the ability to examine variation by number of incidences in this analysis.

Employment losses and divorces are associated with an increase in depression while employment gains are associated with a decrease in depression (appendix A). Marriage shows no effects. Stratifying the analysis by gender suggests that the effect due to employment losses is driven by men whereas the effect due to divorce is driven by women. There is a strong negative association between employment losses and self-rated health for both men and women (appendix B). Results for women suggest an increase in self-rated health from employment gains. Results for marriage and divorce are not significant, which is likely a reflection of the smaller sample size. Taken as a whole, these results indeed reflect the same associations that the previous logistic models for the full sample showed.

The NLSY79 asks the same CES-D battery of questions in 1992 (7-item and 20-item versions) and 1994 (7-item version only). I use these questions to construct a depression score at age 30 (using those who were age 27-30 in 1992 and 1994). If the 20item score is available in 1992, I use that value first, and then I fill in missing values with the other scores. Since events that occurred prior to age 30 pre-date this CES-D score, I create new event variables that only include events between ages 30 and 40 in the same way as explained previously for events between ages 40 and 50; again, I face the limitation of not being able to examine counts of events but rather focus on a dichotomous indicator of event occurrence only. Again, the direction of each event's effects on depression are the same as previous results, though only results for employment loss and divorce (for men only) are significant (appendix C).

There are innovative methodological techniques by which to address reverse causality, calculating an average treatment effect (ATE) for the population, which is the "mean causal effect for a unit whose characteristics are represented by [a set of covariates]" (Ho, Imai, King, \& Stuart, 2007:204), or an average treatment effect on the treated (ATT), 
which is the mean causal effect for individuals who did experience the treatment/event. These techniques do not solve reverse causality outright, but they allow for more robust estimates and sensitivity analyses. To use one such pathway, I define potential selection by pre-existing health measures as a source of pre-treatment heterogeneity, since this is defined as "the propensity of selection into treatment" (Xie, Brand \& Jann, 2012:2). This allows me to look at potential variation in effects due to pre-treatment selection (Brand \& Simon Thomas, 2013; Xie, Brand \& Jann, 2012). If there is systematic variation in effects by strata, created using pre-treatment controls, this provides evidence of reverse causality. As pretreatment controls, I use the same control variables used in previous models, including event variables for the event not being addressed in each model, to calculate propensity scores for each event. I use logistic models to calculate propensity scores, at the default 0.01 significance level for balancing, using kernel matching for least bias (Morgan \& Winship, 2007) and most sample inclusion (Caliendo \& Kopeinig 2005; Garrido et al., 2014). Strata with few values are combined with the nearest neighboring stratum, following Harder, Stuart, and Anthony (2010). These propensity scores can be broken into strata by their values, and then results can be examined for each stratum and compared to each other. I do this for both the full sample, the sample of events between ages 30 and 40, and the sample of events between ages 40 and 50; in the first set of models, I again use health limitations at age 18 as a pre-treatment control variable, in the second set of models, I use the CES-D score at age 30 as this control, and in the third set I use the CES-D or selfrated health score at age 40 as this control.

Graphs of effects across strata (available upon request) do not show any specific patterns, for selfrated health or depression outcomes. For all three samples, effects do not clearly show a pattern across strata. I conclude that this sensitivity analysis does not show evidence of reverse causality. Events are more likely for those who experience other events (i.e. they have a higher propensity score for each event) more so than for those who have a history of poorer mental or physical health, which again speaks to the importance of the context of other events.

I use propensity scores to create weights, using the same control variables and logistic regression models to calculate weights. I 'weigh' each observation by the inverse of the propensity to be selected (Inverse Probability of Treatment Weights, or IPTW). In other words, those respondents who are highly likely to experience an event (i.e. receive the treatment) are 'down-weighted' and those who are less likely to experience an event are 'upweighted' (Sampson, Sharkey \& Raudenbush, 2008).

Since treatment assignment indeed appears to be 'ignorable', meaning that "there are no unobserved covariates related to the outcome that are also predictive of treatment group assignment once the observed covariates are controlled" (Sampson, Sharkey \& Raudenbush, 2007:846), it is appropriate to continue with the IPTW analysis (see also Statacorp, 2013). Again, this means that logistic regression models are run similarly to the previous models, with the important inclusion of survey weights, which are inversely related to the probability of being treated, or experiencing an event. Thus, these survey weights adjust for the probability of experiencing events. Further information on covariate balance in the treatment weights is included in appendix $F$ (for events during ages 18 and 40; similar statistics are available upon request for models for other age ranges). Overall results from the IPTW model are remarkably similar to prior results (appendix D), as shown in tables 2 and 3 (for the full sample), appendices $A$ and $B$ (for the ages 40-50 sample), and $C$ (for the ages 30-40 sample). Again, employment losses and divorces are, on the whole, detrimental to one's physical and mental health, while employment gains show significant benefits for self-rated health (effects on depression are insignificant but in the direction of improvement), and marriages show mainly advantageous results.

These analyses by no means entirely disprove reverse causality. Indeed, unobserved covariates (e.g. concurrent health changes or underlying health issues exacerbated by the stress of disruptive events) could still cause biased estimates (see e.g. Sampson, Sharkey \& Raudenbush (2008) for further discussion). However, the various analyses presented in this section do support estimates from prior models, providing consistency across model specifications and methodology.

\section{Exploring temporal distance from events}

Events that occurred during the earlier (18-25) age range are necessarily more temporally distant from the outcome at age 40 than events in the later 
age range (26-40). This means that effects from earlier events could have waned over time, whereas later events could be more salient at the time of the outcome. To test this possibility, I look at events occurring in the earlier age range, using variables for each number of incidences as in previous models, and use the CES-D score at age 30 as the outcome (self-rated health questions are not available at other ages). This makes the outcome more proximate to earlier events' occurrences.

Indeed, employment losses and divorces increase chances of depression, whereas marriage decreases these chances (appendix E). Employment gains are insignificant, though suggestive of providing a decrease in depression. Comparing these results to the $18-25$ column in table 4 , this suggests that over time, the effects of employment losses and gains from this earlier age range are exacerbated rather than waning. On the other hand, the effects of divorce and higher counts of marriages show some evidence of waning over time, further underscoring the increased effects from events occurring in the later age range. Thus, temporal proximity does matter to a certain extent, but generally effects are persistent over time. This corroborates the idea that the later age is a more sensitive period for event occurrence. Again, this sensitivity analysis is only possible for CES-D scores, not self-rated health outcomes, so these conclusions are drawn with caution.

\section{Effect trends across ages}

Though the distinction between early and later adulthood as being $18-25$ versus $26-40$ is established in literature (Kasl \& Jones, 2000), it is nonetheless useful for comparison to look at trends across the full age range (18-40 years old). Thus, I run separate logistic regression models for event variables at each age. I include the same control variables as in previous models, as well as controls for having ever experienced other events between ages 18 and 40. I graph the coefficients across ages and force a linear trend line to see potential patterns.

Though standard errors are large for these estimates, given the small sample sizes of those who experience events, and therefore the values of estimates are independently not particularly informative, the pattern of effects can easily be seen in figures $1 \mathrm{a}$ and $1 \mathrm{~b}$. Results indicate that the pattern of effects from the previous analysis is upheld. For self-rated health (figure 1a), the effects of employment losses become more negative across age. Employment gains become more positive. Effects of marriage and divorce both improve slightly over time. For depression (figure $1 b)$, both employment losses and divorce lead to increased effects on depression across age, whereas employment gains and marriages show slight decreases.

\section{Discussion}

The analyses presented in this paper look at employment losses and gains, marriage, and divorce to see how these disruptive transitions affect physical and mental health at age 40 . I find that employment losses decrease self-rated health and increase depression. This is true for both men and women, though effects on depression are stronger for women (which complements research showing higher levels of depression among women (Mirowsky, 1996) but counters research showing stronger effects of unemployment on mental health for men (Paul \& Moser, 2009)) and effects on selfrated health are stronger for men (following evidence that employment loss increases mortality among men (Morris et al., 1994)). Employment gains, conversely, improve health by decreasing depression and increasing self-rated health (which follows work that shows reversal of the healthdamaging effects of job loss by reemployment (Kessler, Turner \& House, 1989)). Again, effects on depression are stronger for women and effects on self-rated health are stronger for men. Marriages lead to some decreases in depression for women specifically (which is not surprising; e.g. KiecoltGlaser \& Newton, 2001); divorces lead to increases in depression in women and decreases in self-rated health for men and women. Thus, employment and partner losses appear to have similar effects as do employment and partner gains.

Beyond gender differences, there are other nuances. First, timing matters: employment transitions lead to worse health outcomes when they occur later in adulthood, whereas marital transitions affect self-rated health more strongly when they occur in early adulthood and depression more strongly when they occur in later adulthood. Second, the numbers of incidences matter: those who experience a larger number of employment transitions have worse health outcomes. For numbers of marital transitions, evidence is more mixed, with respondents who experienced one marriage in the same time span showing greater 
Figure 1a.

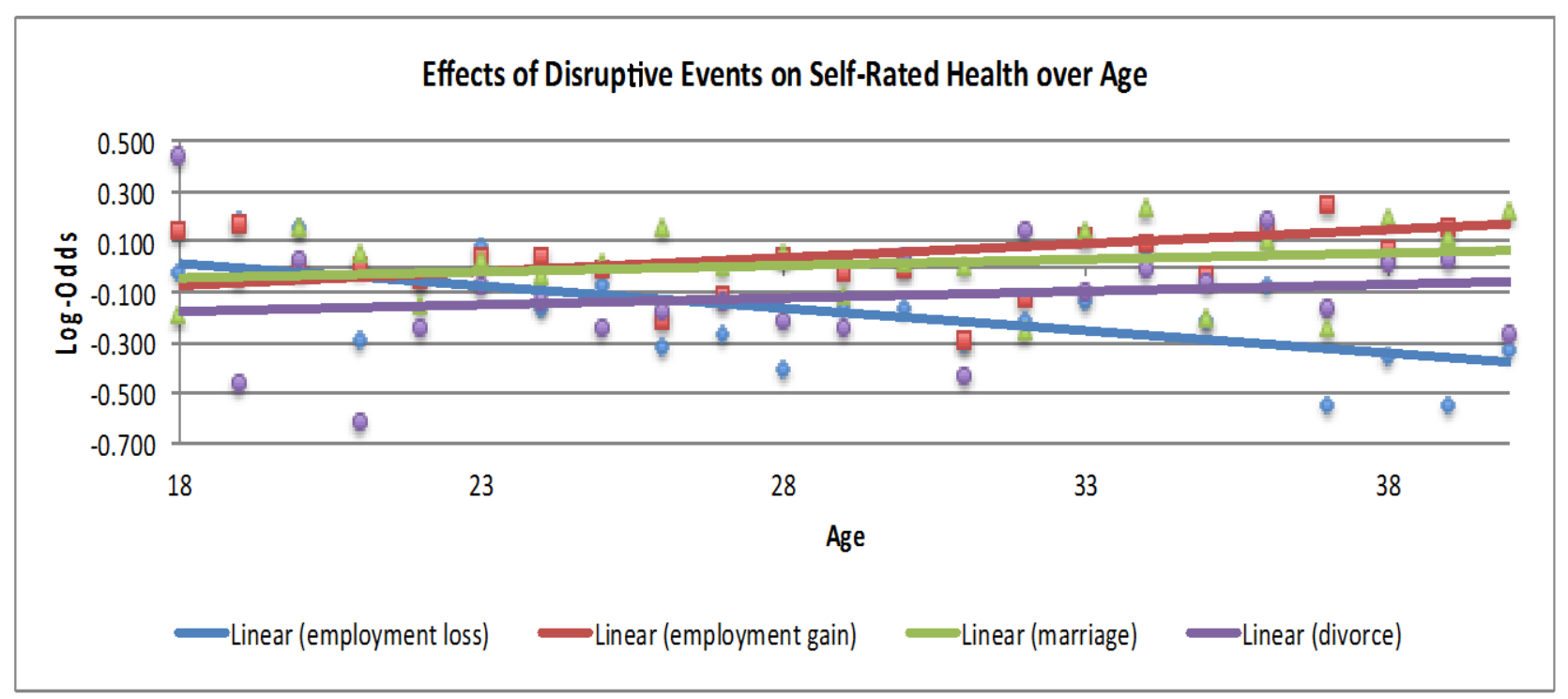

Figure 1b.

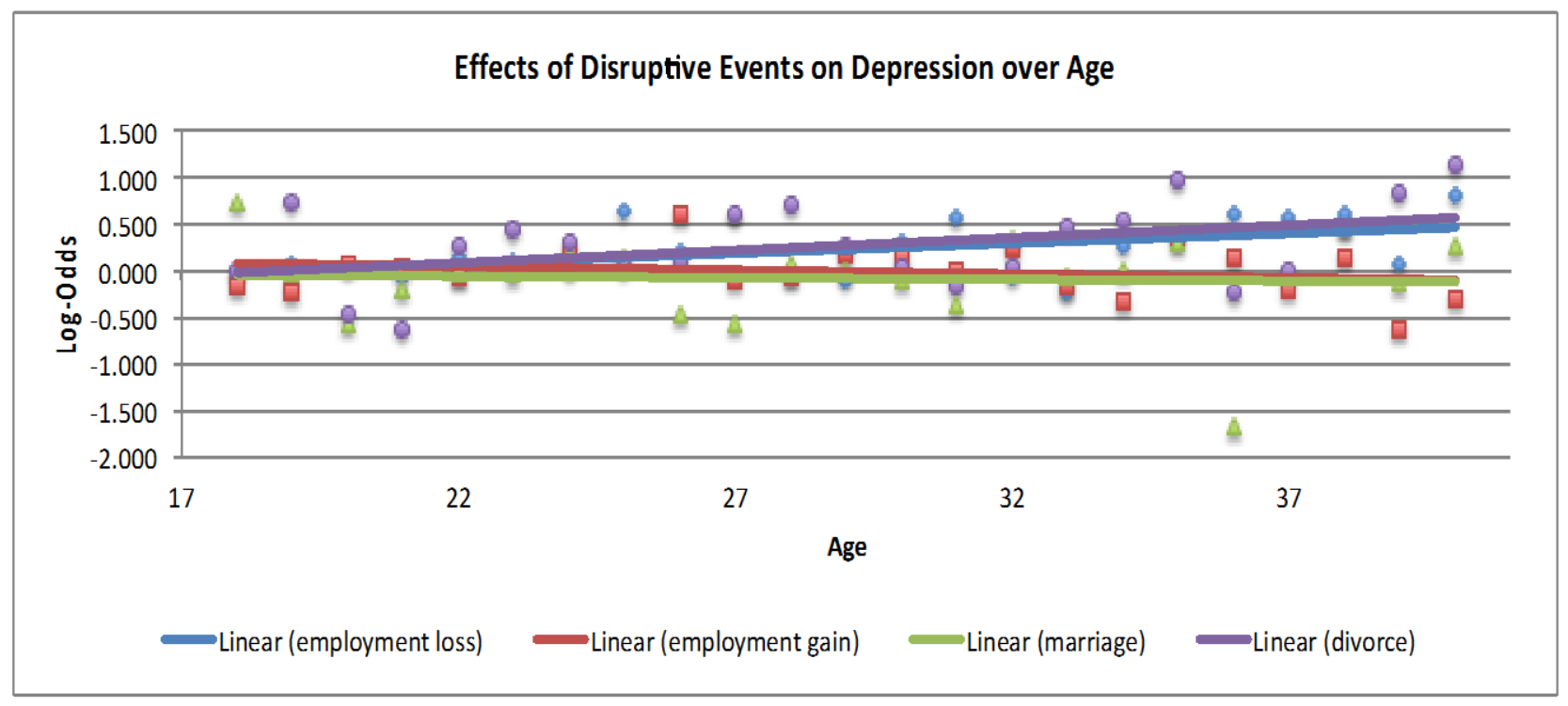


health benefits as compared to those who experienced two marriages, while those who experienced two or more divorces in the same time span show lower self-rated health but no differences in depression when comparing those same groups.

This paper aims to bring together findings from two domains of disruptive life events - work and family - as these are transitions that are relatively commonly experienced by many people. Allowing these transitions to co-exist shows the effects of each event within the context of other transitions that might be happening in the life course. Though seemingly positive transitions such as marriage and employment gains show improvements in health, overall, they do not fully 'offset' transitions such as divorce and employment losses, which could go hand-in-hand with the more positive events. Indeed, looking at a simple event count of all four events combined into one variable shows a 0.052 decrease in the log-odds of self-rated health for each additional event and a 0.078 increase in the log-odds of depression for each additional event (full results available upon request).This speaks to literature on the negative effects of instability (e.g. Osborne \& McLanahan, 2007): a greater count of events means more instability and worse health outcomes, even when some included events seem like positive transitions. I speculate that that cumulative disadvantage (DiPrete \& Eirich, 2006), biological wear and tear (Geronimus, 1996; Hayward et al., 2000; Seeman et al., 2001), and role history (Wheaton, 1990) could be explanations for increased effects with an increased number of transitions, though I do not test these theories directly. Since people often do not experience one disruptive transition in isolation of other transitions, this context is important to understanding how events matter in the life course. A relevant next step might be to characterise combinations of events into pathways (e.g. Eliason, Mortimer \& Vuolo, 2015) to see how different pathways alter health outcomes.

Importantly, the results show that there are similarities across work and family domains in terms of the effects that transitions evoke on health outcomes; moreover, experiencing several transitions, within the same or different domains, can lead to important overlaps in effects that might lessen or worsen health outcomes overall. Thus, considering experiences of transitions across work and family domains matters for health outcomes.

\section{Acknowledgements}

I thank Jason Beckfield, Lisa Berkman, and Subu Subramanian for helpful comments and suggestions.

\section{References}

Adler, N. E., Boyce, T., Chesney, M. A., Cohen, S., Folkman, S., Kahn, R. L., \& Syme, S. L. (1994).

Socioeconomic status and health: The challenge of the gradient. American Psychologist, 49(1), 15-

24. https://doi.org/10.1037/0003-066X.49.1.15

Adler, N. E. \& Ostrove, J. M. (1999). Socioeconomic Status and Health: What We Know and What We Don't.

Annals of the New York Academy of Sciences, 896, 3-15. https://doi.org/10.1111/i.17496632.1999.tb08101.x

Ali, J. \& Avison, W. R. (1997). Employment Transitions and Psychological Distress: The Contrasting Experiences of Single and Married Mothers. Journal of Health and Social Behavior, 38, 345-362. https://doi.org/10.2307/2955430

Backhans, M. C. \& Hemmingsson. T. (2011). Unemployment and Mental Health - Who Is (Not) Affected? The European Journal of Public Health, 22(3), 429-33. https://doi.org/10.1093/eurpub/ckr059

Bambra, C. (2011). Work, Worklessness, and the Political Economy of Health. Oxford: Oxford University Press. https://doi.org/10.1093/acprof:oso/9780199588299.001.0001

Bambra, C. (2014). Health Inequalities, Work, and Welfare. The Wiley Blackwell Encyclopedia of Health, IIIness, Behavior, and Society. Pp. 989-992.

Bartley, M., Ferrie, J., \& Montgomery, S. M. (2006). Health and Labour Market Disadvantage: Unemployment, Non-Employment, and Job Insecurity. In M. Marmot and R. G. Wilkinson (Eds.), Social Determinants of Health (78-96). Oxford: Oxford University Press. 
Ben-Shlomo, Y. \& Kuh, D. (2002). A Life Course Approach to Chronic Disease Epidemiology: Conceptual Models, Empirical Challenges and Interdisciplinary Perspectives. International Journal of Epidemiology, 31(2), 285-93. https://doi.org/10.1093/intjepid/31.2.285

Bird, C. E. \& Rieker, P. P. (1999). Gender Matters: An Integrated Model for Understanding Men's and Women's Health. Social Science and Medicine, 48, 745-755. https://doi.org/10.1016/S02779536(98)00402-X

Blane, D. (2006). The Life Course, the Social Gradient, and Health. In M. Marmot and R. G. Wilkinson (Eds.), Social Determinants of Health (54-77). Oxford: Oxford University Press.

Blekesaune, M. (2008). Partnership Transitions and Mental Distress: Investigating Temporal Order. Journal of Marriage and Family, 70, 879-890. https://doi.org/10.1111/j.1741-3737.2008.00533.x

Booth, A. \& Amato, P. R. (2001). Parental Predivorce Relations and Offspring Postdivorce Well-Being. Journal of Marriage and Family, 63,197-212. https://doi.org/10.1111/j.1741-3737.2001.00197.x

Brand, J. E. \& Simon Thomas, J. (2013). Causal Effect Heterogeneity. In S. L. Morgan (Ed.), Handbook of Causal Analysis for Social Research (189-213). Dordrecht: Springer Publishing.

Bronfenbrenner, U. (2004). Making Human Beings Human: Bioecological Perspectives on Human Development. Thousand Oaks, CA: SAGE Publications, Inc.

Bureau of Labor Statistics, U.S. Department of Labor. National Longitudinal Survey of Youth 1979 cohort, 1979-2012 (rounds 1-25). (2012). Produced and distributed by the Center for Human Resource Research, Ohio State University, Columbus, $\mathrm{OH}$.

Bureau of Labor Statistics, U.S. Department of Labor. Sample Weights and Clustering Adjustments. 2016. Retrieved from https://www.nlsinfo.org/ content/cohorts/nlsy79/using- and-understanding-thedata/ sample-weights-clustering- adjustments on May 5, 2016.

Burgard, S. A., Brand, J. E. \& House, J. S. (2009). Perceived Job Insecurity and Worker Health in the United States. Social Science \& Medicine, 69(5), 777-85. https://doi.org/10.1016/j.socscimed.2009.06.029

Caliendo, M. \& Kopeinig, S. (2005). Some Practical Guidance for the Implementation of Propensity Score Matching. IZA (Institute for the Study of Labor) Discussion Paper No. 1588.

Case, A. \& Paxson, C. (2005). Sex Differences in Morbidity and Mortality. Demography, 42(2), 189-214. https://doi.org/10.1353/dem.2005.0011

Charles, K. K., \& Stephens Jr., M. (2004). Job Displacement, Disability, and Divorce. Journal of Labor Economics, 22, 489-522. https://doi.org/10.1086/381258

Cheung, Y. B. \& Sloggett, A. (1998). Health and Adverse Selection Into Marriage. Public Health, 112(5), 30911. https://doi.org/10.1038/sj.ph.1900491

Coyne, J. C. \& DeLongis, A. (1986). Going Beyond Social Support: The Role of Social Relationships in Adaptation. Journal of Consulting and Clinical Psychology, 54(4), 454-460. https://doi.org/10.1037/0022-006X.54.4.454

Crimmins, E. M. \& Saito, Y. (2001). Trends in Healthy Life Expectancy in the United States, 1970-1990: Gender, Racial, and Educational Differences. Social Science \& Medicine, 52, 1629-1641. https://doi.org/10.1016/S0277-9536(00)00273-2

Cutler, D. \& Lleras-Muney, A. (2010). Understanding Differences in Health Behaviors by Education. Journal of Health Economics, 29, 1-28. https://doi.org/10.1016/i.jhealeco.2009.10.003

DiPrete, T. A. \& Eirich, G. M. (2006). Cumulative Advantage as a Mechanism for Inequality: a Review of Theoretical and Empirical Developments. Annual Review of Sociology, 32(1), 271-97. https://doi.org/10.1146/annurev.soc.32.061604.123127

Elder, G. H. (1998). The Life Course as Developmental Theory. Child Development, 69(1), 1-12. https://doi.org/10.1111/j.1467-8624.1998.tb06128.x

Elder, G. H., Johnson, M. K., \& Crosnoe, R. (2003). The Emergence and Development of Life Course Theory. In J.T. Mortimer \& M. Shanahan (Eds.), Handbook of the Life Course, (pp. 3-19). New York: Springer Science and Business Media. https://doi.org/10.1007/978-0-306-48247-2 1

Eliason, S. R., Mortimer, J. T. \& Vuolo, M. (2015). The Transition to Adulthood: Life Course Structures and Subjective Perceptions. Social Psychology Quarterly, 78(3), 205-27. 
Evans, G. W., Li, D. \& Whipple, S. S. (2013). Cumulative Risk and Child Development. Psychological Bulletin, 139(6), 1342-96. https://doi.org/10.1037/a0031808

Ferrie, J. (2001). Is Job Insecurity Harmful to Health? Journal of the Royal Society of Medicine, 94, 71-76. https://doi.org/10.1177/014107680109400206

Ferrie, J., Shipley, M. J., Marmot, M., Stansfeld, S. \& Davey Smith, G. (1998). The Health Effects of Major Organisational Change and Job Insecurity. Social Science \& Medicine, 46(2), 243-54. https://doi.org/10.1016/S0277-9536(97)00158-5

Frech, A. \& Damaske, S. (2012). The Relationship between Mothers' Work Pathways and Physical and Mental Health. Journal of Health and Social Behavior, 53(4), 396-412. https://doi.org/10.1177/0022146512453929

Frech, A. \& Williams, K. (2007). Depression and the Psychological Benefits of Entering Marriage. Journal of Health and Social Behavior, 48(2), 149-63. https://doi.org/10.1177/002214650704800204

Garrido, M. M., Kelley, A. S., Paris, J., Roza, K., Meier, D. E., Morrison, R. S. \& Aldridge, M. D. (2014). Methods for Constructing and Assessing Propensity Scores. Health Services Research, 49(5), 1701-1720. https://doi.org/10.1111/1475-6773.12182

Geronimus, A. T. (1996). Black/White Differences in the Relationship of Maternal Age to Birthweight: A Population-Based Test of the Weathering Hypothesis. Social Science and Medicine, 42(4), 589-597. https://doi.org/10.1016/0277-9536(95)00159-X

Goldstein, J. R. \& Kenney, C. T. (2001). Marriage Delayed or Marriage Forgone? New Cohort Forecasts of First Marriage for U.S. Women. American Sociological Review, 66(4), 506-519. https://doi.org/10.2307/3088920

Harder, V. S., Stuart, E. A., \& Anthony, J. C. (2010). Propensity Score Techniques and the Assessment of Measured Covariate Balance to Test Causal Associations in Psychological Research. Psychological Methods, 15(3), 234-249. https://doi.org/10.1037/a0019623

Hawkins, D. N. \& Booth, A. (2005). Unhappily Ever After: Effects of Long-Term, Low-Quality Marriages on Well-Being. Social Forces, 84(1), 451-71. https://doi.org/10.1353/sof.2005.0103

Hayward, M. D., Gorman, B. K. (2004). The Long Arm of Childhood: the Influence of Early-Life Social Conditions on Men's Mortality. Demography, 41(1), 87-107. https://doi.org/10.1353/dem.2004.0005

Hayward, M. D., Miles, T. P., Crimmins, E. M. \& Yang, Y. (2000). The Significance of Socioeconomic Status in Explaining the Racial Gap in Chronic Health Conditions. American Sociological Review, 65(6), 910930. https://doi.org/10.2307/2657519

Ho, D. E., Imai, K., King, G., \& Stuart, E. (2007). Matching As Nonparametric Preprocessing for Reducing Model Dependence in Parametric Causal Inference. Political Analysis, 15(3), 199-236. https://doi.org/10.1093/pan/mpl013

Hughes, M. E. \& Waite, L. J. (2009). Marital Biography and Health at Mid-Life. Journal of Health and Social Behavior, 50(3), 344-58. https://doi.org/10.1177/002214650905000307

Idler, E. L. \& Benyamini, Y. (1997). Self-Rated Health and Mortality: a Review of Twenty-Seven Community Studies. Journal of Health and Social Behavior, 38(1), 21-37. https://doi.org/10.2307/2955359

Karsten, P. \& Moser, K. (2009). Unemployment Impairs Mental Health: Meta-Analyses. Journal of Vocational Behavior, 74(3), 264-82. https://doi.org/10.1016/i.jvb.2009.01.001

Kasl, S. V. \& Jones, B. A. (2000). The Impact of Job Loss and Retirement on Health. In L. F. Berkman \& I. Kawachi (Eds.), Social Epidemiology (118-36).

Kena, G., Hussar, W., McFarland, J., de Brey, C., Musu-Gillette, L., Wang, X., Zhang, J., Rathbun, A., WilkinsonFlicker, S., Diliberti, M., Barmer, A., Bullock Mann, F. \& Dunlop Velez, E. (2016). The Condition of Education 2016 (NCES 2016-144). U.S. Department of Education, National Center for Education Statistics. Washington, DC. Retrieved December 6, 2016 from http://nces.ed.gov/pubsearch

Kessler, R. C., House, J. S. \& Turner, J. B. (1987). Unemployment and Health in a Community Sample. Journal of Health and Social Behavior, 28(1), 51-59. 
Kessler, R. C., Turner, J. B. \& House, J. S. (1989). Unemployment, Reemployment, and Emotional Functioning in a Community Sample. American Sociological Review, 54(4), 648-57. https://doi.org/10.2307/2137140

Kiecolt-Glaser, J. K. \& Newton, T. L. (2001). Marriage and Health: His and Hers. Psychological Bulletin, 127(4), 472-503. https://doi.org/10.1037/0033-2909.127.4.472

Koball, H. L., Moiduddin, E., Henderson, J., Goesling, B. \& Besculides, M. (2010). What Do We Know About the Link Between Marriage and Health? Journal of Family Issues, 31(8), 1019-40. https://doi.org/10.1177/0192513X10365834

Krieger, N., Rowley, D. L., Hermann, A. A., Avery, B. \& Phillips, M. T. (1993). Racism, sexism, and social class: implications for studies of health, disease, and well-being. American Journal of Preventative Medicine, 9(suppl), 82-122. https://doi.org/10.1016/S0749-3797(18)30666-4

Lerner, D., Adler, D. A., Chang, H., Lapitsky, L., Hood, M. Y., Perissinotto, C., Reed, J., McLaughlin, T. J., Berndt, E. R., Rogers, W. H. (2004). Unemployment, Job Retention, and Productivity Loss Among Employees with Depression. Psychiatric Services, 55(12), 1371-78. https://doi.org/10.1176/appi.ps.55.12.1371

Link, B. G. and Phelan, J. (1995). Social Conditions as Fundamental Causes of Disease. Journal of Health and Social Behavior (The State of the Art and Directions for the Future), 80-94. https://doi.org/10.2307/2626958

Liu, H. \& Umberson, D.J. (2008). The Times They Are a Changin': Marital Status and Health Differentials From 1972 to 2003. Journal of Health and Social Behavior, 49(3), 239-53. https://doi.org/10.1177/002214650804900301

Lowe, S. R., Rhodes, J. E. \& Waters, M. C. (2015). Understanding Resilience and Other Trajectories of Psychological Distress: a Mixed-Methods Study of Low-Income Mothers Who Survived Hurricane Katrina. Current Psychology, 34(3), 537-50. https://doi.org/10.1007/s12144-015-9362-6

Marmot, M. (2005). The Status Syndrome: How Social Standing Affects Our Health and Longevity. New York, NY: Owl Books.

Masten, A. S. \& Monn, A. R. (2015). Child and Family Resilience: a Call for Integrated Science, Practice, and Professional Training. Family Relations, 64(1), 5-21. https://doi.org/10.1111/fare.12103

Masten, A. S. (2013). Risk and Resilience in Development. In P. D. Zelazo (Eds.), The Oxford Handbook of Developmental Psychology (pp. 1-31) New York, NY: Oxford University Press.

Masten, A. S. (2014). Global Perspectives on Resilience in Children and Youth. Child Development, 85(1), 620. https://doi.org/10.1111/cdev.12205

Mayer, K. U. (2009). New Directions in Life Course Research. Annual Review of Sociology, 35, 413-433. https://doi.org/10.1146/annurev.soc.34.040507.134619

McLeod, J. D. \& Almazan. E. P. (2004). Connections Between Childhood and Adulthood. In J.T. Mortimer \& M. Shanahan (Eds.), Handbook of the Life Course (pp. 391-411). New York, NY: Springer Publishing.

Mirowsky, J. (1996). Age and the Gender Gap in Depression. Journal of Health and Social Behavior, 37, $362-$ 380. https://doi.org/10.2307/2137263

Moen, P. \& Chermack, K. (2005). Gender Disparities in Health: Strategic Selection, Careers, and Cycles of Control. Journal of Gerontology, 60B, 99-108. https://doi.org/10.1093/geronb/60.Special Issue 2.599

Morgan, S. \& Winship, C. (2007). Counterfactuals and Causal Inference: Methods and Principles for Social Research. Cambridge, UK: Cambridge University Press. https://doi.org/10.1017/CBO9780511804564

Morris, J. K., Cook, D. G. \& Shaper, A. G. (1994). Loss of Employment and Mortality. British Medical Journal, 308, 1135-39. https://doi.org/10.1136/bmj.308.6937.1135

Nathanson, C. A. (1980). Social Roles and Health Status Among Women: The Significance of Employment. Social Science and Medicine, 14A, 463-471.

Nazroo, J. Y. \& Williams, D. R. (2006). The Social Determination of Ethnic/Racial Inequalities in Health. In M. Marmot \& R. G. Wilkinson (Eds.), Social Determinants of Health (pp. 238-266) Oxford: Oxford University Press. 
Noelke, C. \& Beckfield, J. (2014). Recessions, Job Loss, and Mortality Among Older US Adults. American Journal of Public Health, 104(11), 126-34. https://doi.org/10.2105/AJPH.2014.302210

Osborne, C. \& McLanahan, S. (2007). Partnership Instability and Child Well-Being. Journal of Marriage and Family, 69,1065-83. https://doi.org/10.1111/j.1741-3737.2007.00431.x

Palloni, A. (2006). Reproducing Inequalities: Luck, Wallets, and the Enduring Effects of Childhood Health. Demography, 43(4), 587-615. https://doi.org/10.1353/dem.2006.0036

Paul, K., \& Moser, K. (2009). "Unemployment Impairs Mental Health: Meta-Analyses." Journal of Vocational Behavior, 74(3), 264-282. https://doi.org/10.1016/i.jvb.2009.01.001

Prigerson, H. G., Meciejewski, P. K., \& Rosenheck, R. A. (1999). The Effects of Marital Dissolution and Marital Quality on Health and Health Service Use Among Women. Medical Care, 37(9), 858-73. https://doi.org/10.1097/00005650-199909000-00003

Repetti, R. L., Taylor, S. E. \& Seema T. E. (2002). Risky Families: Family Social Environments and the Mental and Physical Health of Offspring. Psychological Bulletin, 128(2), 330-66. https://doi.org/10.1037/0033-2909.128.2.330

Riley, M. W., Riley, J. W. Jr., (1994). Stuctural lag: Past and future. In M. W. Riley, R. L. Kahn, \& A. Foner, (Eds.), Age and structural lag: Society's failure to provide meaningful opportunities in work, family and leisure (pp. 15-36). New York: Wiley.

Sampson, R. J., Sharkey, P., \& Raudenbush, S. W. 2008. Durable Effects of Concentrated Disadvantage on Verbal Ability Among African-American Children. Proceedings of the National Academy of Sciences of the United States of America, 105(3), 845-52. https://doi.org/10.1073/pnas.0710189104

Sayer, L. C., England, P., Allison, P., \& Kangas, N. (2011). She Left, He Left: How Employment and Satisfaction Affect Men's and Women's Decisions to Leave Marriages. American Journal of Sociology, 116(6), 1982-2018. https://doi.org/10.1086/658173

Schnittker, J. (2004). Education and the Changing Shape of the Income Gradient in Health. Journal of Health and Social Behavior, 45(3), 286-305. https://doi.org/10.1177/002214650404500304

Seeman, T. E. \& Crimmins, E. (2001). Social Environment Effects on Health and Aging. Annals of the New York Academy of Sciences, 88-117.

Seeman, T. E., McEwen, B. S., Rowe, J. W., \& Singer, B. H. (2001). Allostatic Load as a Marker of Cumulative Biological Risk: MacArthur Studies of Successful Aging. Proceedings of the National Academy of Sciences of the United States of America, 98(8), 4770-75. https://doi.org/10.1073/pnas.081072698

Sleskova, M., Salonna, F., Geckova, A.M., Nagyova, I., Stewart, R.E., van Dijk, J.P., \& Groothoff, J.W. (2006). Does Parental Unemployment Affect Adolescents' Health? Journal of Adolescent Health, 38(5), 52735. https://doi.org/10.1016/i.jadohealth.2005.03.021

StataCorp (2013). Stata: Release 13. Statistical Software. College Station, TX: StataCorp LP.

Turner, R. J., Thomas, C. S., \& Brown, T. H. (2016). Childhood Adversity and Adult Health: Evaluating Intervening Mechanisms. Social Science and Medicine, 156, 114-124. https://doi.org/10.1016/i.socscimed.2016.02.026

Uecker, J. E. 2012. Marriage and Mental Health Among Young Adults. Journal of Health and Social Behavior, 53(1), 67-83. https://doi.org/10.1177/0022146511419206

Uhlenberg, P. \& Mueller, M. M. (2004). Family Context and Individual Well-Being. In J.T. Mortimer \& M. Shanahan (Eds.), Handbook of the Life Course (pp 391-411). New York, NY: Springer Publishing.

Waldron, I., Hughes, M. E., \& Brooks, T. L. (1996). Marriage Protection and Marriage Selection - Prospective Evidence for Reciprocal Effects of Marital Status and Health. Social Science \& Medicine, 43(1), 11323. https://doi.org/10.1016/0277-9536(95)00347-9

Wheaton, B. (1990). Life Transitions, Role Histories, and Mental Health. American Sociological Review, 55(2), 209-23. https://doi.org/10.2307/2095627

Wheaton, B. (1997). The Nature of Chronic Stress. In B. H. Gottlieb (Ed.), Coping with Chronic Stress (pp. 4373). New York, NY: Springer Publishing. https://doi.org/10.1007/978-1-4757-9862-3 2

Wheaton, B. \& Gotlib, I. H. (1997). Trajectories and Turning Points Over the Life Course: Concepts and Themes. In I.H. Gotlib \& B. Wheaton (Eds.), Stress and Adversity over the Life Course (pp. 1-28). Cambridge: Cambridge University Press. https://doi.org/10.1017/СBO9780511527623.001 
Wooldridge, J. M. (2006). Introductory Econometrics: A Modern Approach. The Thomson Corporation: Thomson South-Western.

Xie, Y., Brand, J. E., \& Jann, B. (2012). Estimating Heterogeneous Treatment Effects with Observational Data. Sociological Methodology, 42(1), 314-47. https://doi.org/10.1177/0081175012452652

\section{Endnotes}

1. Center for Epidemiologic Studies Depression Scale

2. Short Form Health Survey scale 
Appendix D: The Effects of Disruptive Events on Health Outcomes, Using IPTW Models

\begin{tabular}{lccccc}
\hline & \multicolumn{2}{c}{ Full sample (ages 18-40) } & \multicolumn{2}{c}{ Ages 40-50 } & Ages 30-40 \\
\cline { 2 - 6 } \multicolumn{1}{c}{ Event } & Effects on & Effects On Self- & Effects on & Effects on Self- & Effects on \\
Depression & Rated Health & Depression & Rated Health & Depression \\
\hline Employment loss & 0.406 & $-0.370^{* *}$ & $0.775^{*}$ & $-0.747^{* * *}$ & $0.628^{*}$ \\
Employment gain & -0.171 & $0.437^{*}$ & $-0.212^{*}$ & 0.099 & -0.199 \\
Marriage & $-0.839^{*}$ & 0.165 & -0.275 & 0.211 & -0.228 \\
Divorce & $0.792^{* *}$ & $-0.174^{*}$ & 0.544 & 0.144 & 0.257 \\
\hline
\end{tabular}

Notes: Results are log-odds. All models include controls for other events (ever during the corresponding time frame) gender, race, education, ability, number of children, welfare receipt, health limitations on work, and Rotter Locus of Control score. Models are weighted using IPTW.

$+\mathrm{p}<.10 * \mathrm{p}<.05 * * \mathrm{p}<.01 * * * \mathrm{p}<.001 \quad$ (two-tailed tests)

\begin{tabular}{|c|c|c|}
\hline \multicolumn{3}{|c|}{$\begin{array}{c}\text { Appendix E: The Effects of Disruptive } \\
\text { Events (at ages 18-25) on Depression } \\
\text { at age } 30\end{array}$} \\
\hline & & All respondents \\
\hline Event & & $18-25$ \\
\hline \multicolumn{3}{|c|}{ Employment losses } \\
\hline & $1 x$ & 0.121 \\
\hline & $2 x$ & $0.285+$ \\
\hline & $3 x$ & $0.782 * *$ \\
\hline \multicolumn{3}{|l|}{ Employment gains } \\
\hline & $1 x$ & -0.110 \\
\hline & $2 x$ & 0.125 \\
\hline & $3 x$ & -0.438 \\
\hline \multicolumn{3}{|l|}{ Marriage } \\
\hline & $1 x$ & $-0.120 *$ \\
\hline & $2 x$ & $-0.515+$ \\
\hline \multicolumn{3}{|l|}{$\overline{\text { Divorce }}$} \\
\hline & $1 x$ & $0.402 * *$ \\
\hline & $2 x$ & $0.918 *$ \\
\hline Constant & & -0.201 \\
\hline$L R \chi^{2}$ & & 288.00 \\
\hline$P>\chi^{2}$ & & 0.000 \\
\hline Pseudo $R^{2}$ & & 0.076 \\
\hline & & \\
\hline \multicolumn{3}{|c|}{$\begin{array}{l}\text { Notes: Results are log-odds. All models } \\
\text { include controls for gender, race, } \\
\text { education, ability, number of children, } \\
\text { welfare receipt, health limitations on } \\
\text { work, Rotter Locus of Control score, } \\
\text { and Rosenberg Self-Esteem Scale score. } \\
+p<.10 * p<.05 * * p<.01 \\
* * * p<.001 \quad \text { (two-tailed tests) }\end{array}$} \\
\hline
\end{tabular}


Appendix F: Covariate Balance for Inverse Probability of Treatment Weights

\begin{tabular}{|c|c|c|c|c|c|c|c|c|c|c|c|c|}
\hline \multirow[b]{2}{*}{ Covariates } & \multicolumn{3}{|c|}{ Employment Loss } & \multicolumn{3}{|c|}{ Employment Gain } & \multicolumn{3}{|c|}{ Marriage } & \multicolumn{3}{|c|}{ Divorce } \\
\hline & $\begin{array}{l}\text { Mean in } \\
\text { Treated }\end{array}$ & $\begin{array}{c}\text { Mean in } \\
\text { Untreated }\end{array}$ & $\begin{array}{l}\text { Stand. } \\
\text { Diff. }\end{array}$ & $\begin{array}{l}\text { Mean in } \\
\text { Treated }\end{array}$ & $\begin{array}{c}\text { Mean in } \\
\text { Untreated }\end{array}$ & $\begin{array}{l}\text { Stand. } \\
\text { Diff. }\end{array}$ & $\begin{array}{l}\text { Mean in } \\
\text { Treated }\end{array}$ & $\begin{array}{c}\text { Mean in } \\
\text { Untreated }\end{array}$ & $\begin{array}{l}\text { Stand. } \\
\text { Diff. }\end{array}$ & $\begin{array}{l}\text { Mean in } \\
\text { Treated }\end{array}$ & $\begin{array}{c}\text { Mean in } \\
\text { Untreated }\end{array}$ & $\begin{array}{c}\text { Stand. } \\
\text { Diff. }\end{array}$ \\
\hline Employment Loss (ever, by age 40) & - & - & - & 0.72 & 0.74 & -0.051 & 0.72 & 0.70 & 0.040 & 0.71 & 0.72 & -0.009 \\
\hline Employment Gain (ever, by age 40 ) & 0.83 & 0.82 & 0.024 & - & - & - & 0.82 & 0.76 & 0.151 & 0.79 & 0.81 & -0.060 \\
\hline Marriage (ever, by age 40) & 0.73 & 0.72 & 0.028 & 0.73 & 0.73 & -0.007 & - & - & - & 0.70 & 0.73 & -0.062 \\
\hline Divorce (ever, by age 40 ) & 0.36 & 0.36 & 0.011 & 0.36 & 0.34 & 0.040 & 0.36 & 0.57 & -0.525 & - & - & - \\
\hline Male (0/1) & 0.46 & 0.46 & -0.001 & 0.48 & 0.43 & 0.103 & 0.48 & 0.46 & 0.052 & 0.46 & 0.49 & -0.045 \\
\hline Black (0/1) & 0.31 & 0.32 & -0.023 & 0.31 & 0.34 & -0.072 & 0.30 & 0.21 & 0.206 & 0.25 & 0.31 & -0.121 \\
\hline Hispanic $(0 / 1)$ & 0.19 & 0.19 & 0.014 & 0.19 & 0.19 & 0.009 & 0.19 & 0.33 & -0.339 & 0.22 & 0.19 & 0.064 \\
\hline High school only ( $0 / 1$; by age 40$)$ & 0.43 & 0.43 & 0.006 & 0.43 & 0.40 & 0.054 & 0.43 & 0.47 & -0.072 & 0.43 & 0.43 & -0.012 \\
\hline College attendance $(0 / 1$; by age 40$)$ & 0.24 & 0.23 & 0.005 & 0.24 & 0.25 & -0.024 & 0.24 & 0.24 & -0.003 & 0.25 & 0.24 & 0.020 \\
\hline College completion $(0 / 1$; by age 40$)$ & 0.22 & 0.22 & 0.017 & 0.22 & 0.24 & -0.067 & 0.21 & 0.18 & 0.080 & 0.22 & 0.21 & 0.006 \\
\hline Ability $(-3-3)$ & 0.00 & -0.01 & 0.019 & 0.03 & -0.04 & 0.091 & 0.02 & 0.09 & -0.092 & 0.07 & 0.03 & 0.055 \\
\hline Number of children (by age 40) & 1.92 & 1.95 & -0.019 & 1.93 & 1.91 & 0.019 & 1.95 & 3.03 & -0.724 & 2.15 & 1.92 & 0.161 \\
\hline Welfare (between ages 18 and 40 ) & 0.38 & 0.39 & -0.016 & 0.37 & 0.44 & -0.140 & 0.38 & 0.37 & 0.008 & 0.35 & 0.37 & -0.038 \\
\hline Health limits (in 1979) & 0.05 & 0.05 & -0.002 & 0.05 & 0.05 & -0.003 & 0.05 & 0.06 & -0.043 & 0.05 & 0.05 & 0.019 \\
\hline Rotter Locus of Control & 8.76 & 8.78 & -0.007 & 8.75 & 8.93 & -0.075 & 8.73 & 8.52 & 0.087 & 8.57 & 8.73 & -0.064 \\
\hline
\end{tabular}

Notes: Covariates reported here are matched on CESD outcomes. Matches for self-rated health outcomes are closely similar. Rosenberg self-esteem measures are removed from the matching analysis for better balance; model results are not affected by this choice. These are matches generated for models with events during ages 18 to 40. 